\title{
BIOTOPE MAPPING IN AN URBAN ENVIRONMENT FOR SUSTAINABLE URBAN DEVELOPMENT - A CASE STUDY IN SOUTHERN PART OF TURKEY
}

\author{
GÜRKAN, A. \\ Mustafa Kemal University, Faculty of Architecture, Department of Landscape Architecture, \\ 31040 Antakya, Hatay, Turkey \\ (phone: +90-326-221-4112; fax: +90-326-221-1489) \\ *Corresponding author \\ e-mail:aysgmansur@hotmail.com \\ (Received 22 $2^{\text {nd }}$ Jun 2016; accepted $12^{\text {th }}$ Sep 2016)
}

\begin{abstract}
The aim of this contribution is mapping and analysing of biotopes sensitivity in Antakya urban city with its surroundings. The three objectives were: (1) to identify the biotope types which display the structural characteristics of the study area, (2) to map the biotopes using object-oriented classification and (3) to determine sensitivity of these biotopes using rarity and reestablishment of research area. The study mainly carried out in two stages: the first one determination of biotope types using information from field surveys and aerial images; the second stage determination of biotope sensitivity to human disturbance. The sensitivity assessment based on two parameters; the rarity and the re-establishment ability of biotopes. Based on sensitivity results, 1.581 ha of the research area -forest, river banks and river and banks- is very sensitive, 454,6 ha of the research area -cemetery, settlement with site, and maquie- of land sensitive.
\end{abstract}

Keywords: Antakya, object-based classification, re-establishment, rarity, sensitivity, worldview imagery

\section{Introduction}

Cities are complex ecosystems affected by social, economic, environmental, and cultural factors. The problem of attaining urban sustainable development is thus an important challenge ( $\mathrm{Li}$ et al, 2009). Additionally, rapid urbanization and urban sprawl have significant impact on conditions of urban ecosystems. The impact is usually accompanied by many environmental problems, such as a reduction of green spaces and ecosystem deterioration. To maintain a characteristic flora and fauna as well as the functionality of ecosystem, we must consider how land use changes will influence the biotope in urban area (Katarina et al., 2002; Guzelmansur and Kılıç, 2013).

Urban ecosystem services help to maintain sustainable development in urban areas. It depends on the structural parameters of urban green spaces. In order to facilitate the analysis and evaluation of these parameters, a method has been sought to enable the detailed identification of urban ecosystem services on the basis of urban vegetation structures. It is based on the mapping of urban biotope types as well as an analysis ofterrestrial and aerial photographs (Lehman et al., 2014). Biotopes are generally described as a part or element of environment which create suitable conditions for living organisms to be nourished, to shelter, to protect one another, and to contact with each other, and can be limited according to their functional point of view (Foody, 2002). The conceptual basis is the classification of biotopes mainly based on land use and habitat type, as most habitats in urban areas have important social and economic functions, e.g. parks and school grounds (Sukopp and Weiler, 1988; Lo Fvenhaft et al., 2002). 
Geographic Information System give upportunitiy to analyse and evaluate urban ecosystem servises with help of biotope mapping. Rapid development of GIS and remote sensing techniques gives new opportunities in vegetation science (Cserhalmi and Erdos, 2016). Object-based image analysis is quickly gaining acceptance among remote sensors, and has demonstrated great potential for classification and change detection, compared to pixel-based approach (Blanschke, 2010; Myint et al., 2011; Zhou and Troy, 2008; Yu et al., 2016). The advantage of the object-based approach is that it offers new possibilities for image analysis because image objects can be characterised by features of different origin incorporating spectral values, texture, shape, context relationships and thematic or continuous information supplied by ancillary data. Integration of additional knowledge is a valuable means to distinguish ecologically meaningful habitat types that don't have necessarily very distinct spectral features. Moreover integration with existing vector-databases can be achived during all steps of the classification proces (Bock et al., 2005)

The aim of this contribution is mapping and analyzing of biotopes sensitivity in Antakya urban city with its surroundings. The study which performed with the help of RS and GIS mainly consists of three objectives: (1) to identify the biotope types which display the structural characteristics of the study area (2) to map the biotopes using object-oriented classification and (3) to determine sensitivity of these biotopes using rarity and re-establishment of research area.

\section{Materials and Methods}

\section{Study area}

Antakya is a city in the Mediterranean region of the southern part of Turkey, with a population of 500.749 (Tüik, 2016) (Fig.1). The study area is a $8 * 9 \mathrm{~km}$ area including the Antakta city center. It is surrounded by forest cover of Amanos Mountain in the west, Amik Plain in the north and Habibi Neccar Mountain in the east. Orontes River is the main river which is across the urban area. Climate regime is Mediterranean climate characterized by a mild winter during which about $67 \%$ of the annual precipitation of $1124 \mathrm{~mm}$ falls, and a hot dry summer. Average annual temperature reaches a maximum of $44^{\circ}$ in the summer and a minimum of $-15 \mathrm{C}^{\circ}$ in the winter, with an average annual temperature of $18{ }^{\circ} \mathrm{C}$. Parent material consists mostly of conglomera, calcaire and alluvial. Mediterranean vegetation consists of evergreen forest of Pinus brutia, and shrublands composed of maquis, and garrigues (Guzelmansur and Kılıç, 2013). There are 1861 taxons (223 of them endemic) of natural vegetation in the whole city (Davis et al, 1988). Regressive succession stages of evergreen forests have taken place under drastic human induced disturbances such as overgrazing, overcutting and clearance for cultivation.

\section{Methodology}

The study comprises 2 stages: (1) determination of biotope types using information from field surveys and aerial images, (2) determination of biotope sensitivity using rarity and reestablishment. 


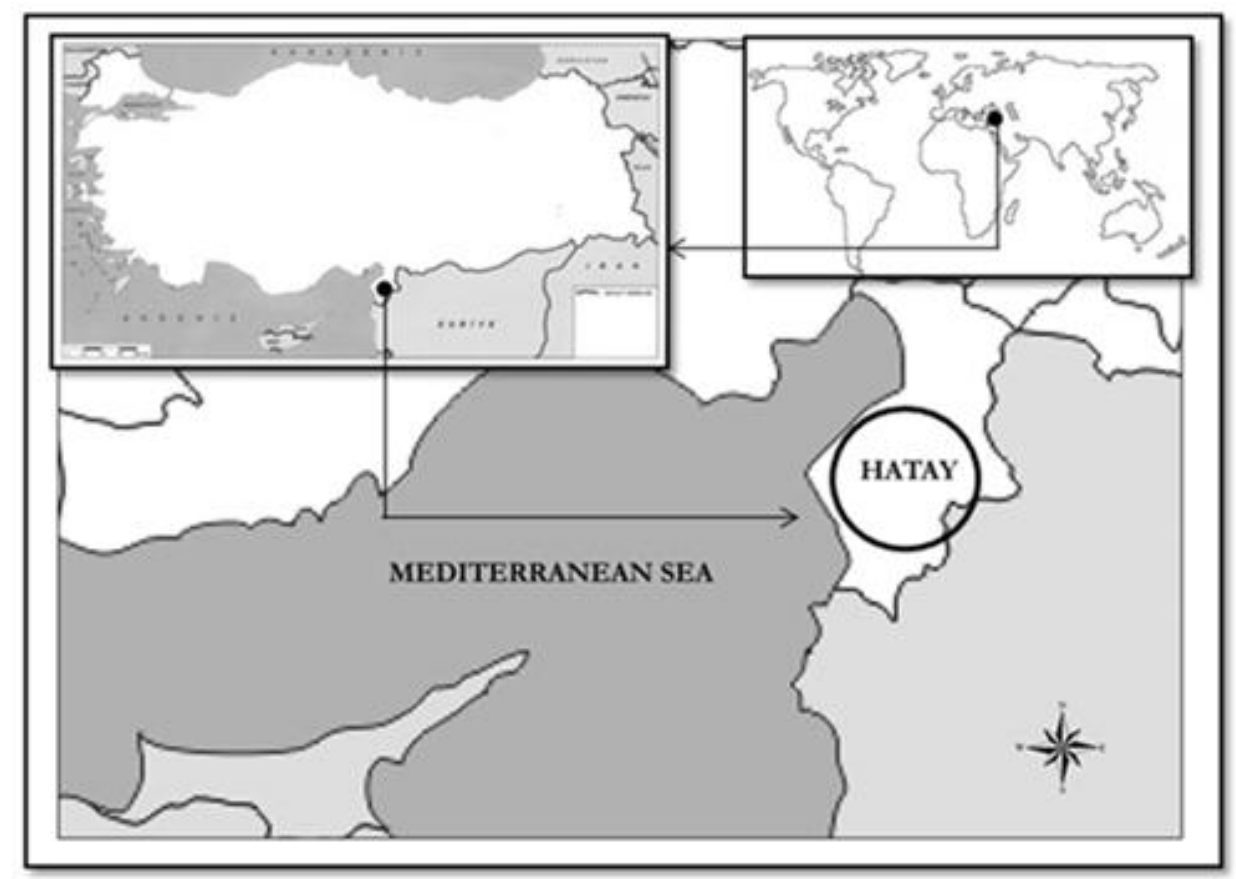

Figure 1. Site location of study area.

Determination of biotope types using information from field surveys and aerial images

Determination of biotope types whic is an important item for urban ecosystem services give an opportunity to maintain sustainable urban development. Urban ecosystem services depend on the structural parameters of urban green spaces. It is based on the mapping of urban biotope types as well as an analysis ofterrestrial and aerial photographs. It enables the identification and description of all areas within a city characterized by vegetation according to type, size, structural characterization as well as density, structure and building type (Lehmann et al., 2014). Basic information about the area of investigation, its ecology, species, etc., is to be gathered and selected. In Antakya city, floristic data were available through publications, former mappings, unpublished species lists and species distribution maps, expert's reports, expert knowledge, local literature and other local information from citizens. Further data were supplied from field work with expert of vegetation (Frey, 1999).

Worldview Ortoready Pansharpened (WV2-NT/ORPNP) collected on September 2014 was used in this study. The image data has $50 \mathrm{~cm}$ spatial resolution and comprise three wavebands and 16 bites. The image geometrically corrected and geocoded to the UTM-WGS 84, zone 37. Object-based analysis method was preferred in the classification process. Primarily stuctural aspect rather than functional characteristics of vegetation and land use structures (as well as undeveloped sites) that are relevant to mapping of biotopes. Image objects are described and classified by using a wide range of attributes including image features such as spectral variables, shape, texture, size, but also potentially thematic data such as slope, aspect, soil properties provided by digital maps. Image objects may also be classified by reference to expert rules such as rules based on the spatial relationship between objects (contiguity) or the distance between objects (Mathieu et al., 2007). The software used in this research, ArcGIS 10.2. Objectoriented techniques have been recently used in a wide range of application fields, 
examples in: habitat mapping (Bock, 2003), landscape pattern analysis (Ivits et al., 2005), fire monitoring (Gitas et al., 2004), land cover/land use mapping in rural (Van der Sande et al., 2003) or urban environments (Meinel et al., 2001) and topographic feature extraction (Repaka et al., 2004; Mathieu et al., 2007). 3 main categories of biotope types were identified: (1) built-up, (2) non-built-up, (3) agricultural area. These 3 categories were divided into 19 sub biotope types. Additionally, field surveys were carried out to verify these biotope types by visual inspection by experts.

\section{Determination of biotope sensitivity to human disturbance}

Biotope sensitivity analysis method used which developed by Altan (1997); Guzelmansur (2000); Mansuroğlu et al. (2006), which is based on two parameters to assess the biotope sensitivity to human disturbance: 1) the rarity of biotopes and 2) the re-establishment ability (Table 1).

The rarity of biotopes was evaluated at the level of Antakya city. The degrees of rarity of urban biotopes were determined according to the rarity classification of Altan (1997): I.Very rare (VR): Those biotopes standing alone or distributed in a very restricted area; II.Rare (R): Those biotopes limited in numbers or distributed in a restricted area; III.Partly present (PP): Those biotopes seen at intervals in large areas sufficiently; IV.Sufficiently present (SP): Those biotopes regularly seen in large areas.

The re-establishment of a destroyed or negatively affected biotope depends on the regeneration processes of plants and other natural elements (Altan, 1997). In this study, the following classification which developed by Kaule and Schober (1985) for the reestablishment ability of biotopes (Altan, 1997; Güzelmansur, 2000): I.Reestablishment impossible (RI): Those biotopes need more than 50 years for reestablishment; II.Re-establishment very difficult (RVD): Those biotopes need 25-50 years for re-establishment; III.Re-establishment partly possible (RPP): Those biotopes need 5-25 years for re-establishment; IV.Re-establishment possible (RP): Those biotops need about 5 years for re-establishment.

Table 1 shows the sensitivity matrix according to rarity and re-establishment (Altan, 1997; Güzelmansur, 2000).

Table 1. Sensitivity matrix of biotops acording to rarity and re-establishment (Altan, 1997; Güzelmansur, 2000).

\begin{tabular}{l|c|c|l|l}
\hline \multirow{2}{*}{ Rarity } & \multicolumn{4}{|c}{ Re-establishment } \\
\cline { 2 - 5 } & $\begin{array}{l}\text { Impossible } \\
\text { (RI) }\end{array}$ & $\begin{array}{c}\text { Very difficult } \\
\text { (RVD) }\end{array}$ & $\begin{array}{l}\text { Partly possible } \\
\text { (RPP) }\end{array}$ & $\begin{array}{l}\text { Possible } \\
\text { (RP) }\end{array}$ \\
\hline Very rare (VR) & I & I & II & II \\
Rare (R) & I & I & II & II \\
Partly present (PP) & I & II & II & III \\
Sufficiently present (SP) & II & II & III & IV \\
\hline
\end{tabular}

\section{Results}

Urban biotope types are identified and defined by structural aspects. 3 main biotope types of study area were identified: (1) "Built up", (2) "Non-built-up", and (3) "Agricultural area". The three main categories were divided into 19 supbiotopes. After that the defined biotope types mapped using object-oriented classification with help of field surveys. Finally sensitivity analysis developed using rarity and reestablisment of biotopes. 
Based on biotope map, built-up areas have 3467,788 ha and cover the largest area among all biotopes, non-built-up areas have 2351,79 ha, and agriculture have 2023,1 ha. (Table 2) (Figure 2). On the other hand, built-up areas biotope group has the highest parcels around them. In other words, this biotope group is the most fragmented constituting number of parcels.

Table 2. Biotope types and sensitivity assessment of the City of Antakya and its environs

\begin{tabular}{|c|c|c|c|c|c|c|}
\hline \multirow{2}{*}{\multicolumn{2}{|c|}{ Biotopes }} & \multicolumn{2}{|c|}{ Area } & \multicolumn{3}{|c|}{ Sensitivity } \\
\hline & & \multirow{2}{*}{$\begin{aligned} & \text { ha } \\
& 24,3\end{aligned}$} & \multirow{2}{*}{$\begin{array}{l}\% \\
0,31\end{array}$} & \multirow{2}{*}{$\begin{array}{l}\text { Rarety } \\
\text { Degree } \\
\text { PP }\end{array}$} & \multirow{2}{*}{$\begin{array}{l}\text { Re- } \\
\text { establishment } \\
\text { RPP }\end{array}$} & \multirow{2}{*}{\begin{tabular}{|l|l}
$\begin{array}{l}\text { Sensitivity } \\
\text { degree }\end{array}$ \\
II
\end{tabular}} \\
\hline \multirow{11}{*}{ Built-up } & Cemetery & & & & & \\
\hline & Open pit-mines & 46,7 & 0,60 & SP & $\mathrm{RP}$ & IV \\
\hline & Commercial institutions & 342,1 & 4,36 & SP & $\mathrm{RP}$ & IV \\
\hline & Educational institutions & 49,0 & 0,62 & SP & $\mathrm{RP}$ & IV \\
\hline & Recreational institutions & 14,4 & 0,18 & PP & $\mathrm{RP}$ & III \\
\hline & Parks & 38,8 & 0,49 & PP & $\mathrm{RP}$ & III \\
\hline & Settlement (garden houses) & 346,6 & 4,42 & SP & $\mathrm{RP}$ & IV \\
\hline & Settlement (multi story) & 937,6 & 11,95 & SP & $\mathrm{RP}$ & IV \\
\hline & Settlement (site) & 50,6 & 0,64 & $\mathrm{R}$ & RPP & II \\
\hline & Settlement (low density) & 1598,6 & 20,38 & SP & $\mathrm{RP}$ & IV \\
\hline & Other Public Inst & 19,2 & 0,24 & SP & $\mathrm{RP}$ & IV \\
\hline \multirow{6}{*}{$\begin{array}{l}\text { Non-built- } \\
\text { up }\end{array}$} & Forest & 1238,7 & 15,79 & PP & RI & I \\
\hline & River bank & 275,4 & 3,51 & $\mathrm{R}$ & RI & I \\
\hline & River and Banks & 69,9 & 0,89 & $\mathrm{R}$ & RI & I \\
\hline & Maquie & 379,7 & 4,84 & SP & RVD & II \\
\hline & Garrique & 285,6 & 3,64 & SP & RPP & III \\
\hline & Open areas & 102,5 & 1,31 & SP & $\mathrm{RP}$ & IV \\
\hline \multirow{3}{*}{$\begin{array}{l}\begin{array}{c}\text { Agricultural } \\
\text { area }\end{array} \\
\text { Total }\end{array}$} & Agriculture (annual) & 1700,7 & 21,69 & SP & $\mathrm{RP}$ & IV \\
\hline & Horticulture & 322,3 & 4,11 & SP & RPP & III \\
\hline & & 7842,6 & 100,00 & & & \\
\hline
\end{tabular}

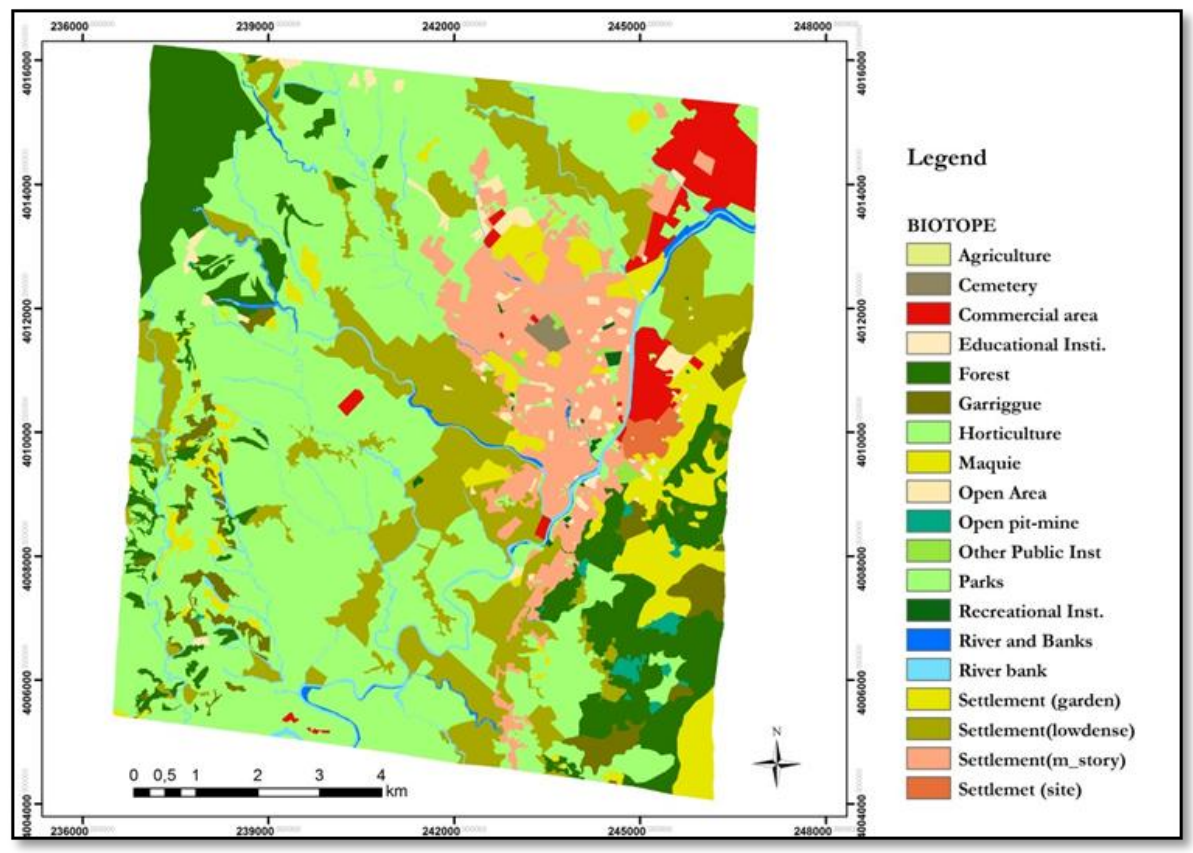

Figure 2. Biotope map of the City of Antakya and its environs. 


\section{Built up areas}

Largest sub biotope area among the biotope is settlement with low density with the rate of $20,40 \%$. Settlement (multi story) $11,95 \%$, Settlement (garden houses) $4,42 \%$, commercial institutions $4,36 \%$, settlement (site) $0,64 \%$, educational institutions $0,62 \%$, open pit-mines $0,60 \%$, parks $0,49 \%$, cemetery $0,31 \%$, other public institutions $0,24 \%$, respectively.

\section{Cemetery}

Cemeteries have different structure in the urban area. These are greenest area in Antakya city. Cupressus sempervirens L. var. pyramidalis is dominant and very common tree. The other thress and srubs are; Cupressus sempervirens L. var. horizontalis, Cupressus arizonica Greene, Callistemon viminalis (Sol. Ex Gaertn.) G.Don. Some ruderal annual plants are; Iris germanica L., Plantago lanceolata L., Anagallis arvensis L., Inula viscosa (L.) Aiton.

\section{Open pit-mines}

Garrigue formations exist around three of mines.

\section{Commercial, educational, recreational institutions}

All of them host some woody plants. Most common woody plants are; Platanus orientalis L., Cupressus sempervirens var. horizontalis (Mill.) Loudon, C. macrocarpa Hartw, Pinus brutia Ten., Eucalyptus camaldulensis Dehnh., Washingtonia filifera (Linden ex Andre) H. Wendl ex de Bary, Morus alba L., Fraxinus excelsior L., Robinia pseudoacacia L., Thuja orientalis L., Pittosporum tobira (Thunb.) W.T.Aiton, Buxus sempervirens L.. Commercial areas consist from Antakya small industrial sites and the other commercial area, while recreational institutions comprise sports areas, amphitheater and playgrounds. These biotopes endowed by exotic ornamental plants. Some of the most commonly seen tree and shrub species in these areas are Acer negundo L., Melia azedarach L., Viburnum tinus L., Rosmarinus officinalis L., Ligustrum vulgare L., Nerium oleander L., Populus alba L., Morus alba L., Laurus nobilis L.. Araucaria excelsa (Lamb.) R.Br., Chamaecyparis lawsoniana (A. Murray bis) Parl., Cupressocyparis leylandii (A.B.Jacks. \& Dallim.) Dallim., Cycas revolute Thunb., Magnolia grandiflora L., Phoenix canariensis Chabaud, Phoenix dactylifera L., Albizzia julibrissin Durazz., Brachychiton populneus (Schott \& Endl.) R.Br., Callistemon viminalis (Sol. Ex Gaertn.) G.Don., Casuarina equisetifolia L., Catalpa bignonioides Walter, Ceratonia siliqua L., Cedrus libani A.Rich., Cotoneaster acutifolius Turcz, Fraxinus exelsior L., Grevillea robusta A.Cunn. ex R.Br., Koelreuteria paniculata Laxm., Ligustrum japonicum Thunb., Liquidambar orientalis Mill.. Some annual plants: Glycyrrhiza glabra L., Avena sp., Lactuca sp, Trifolium angustifolium L., Plantago sp., Centaurea iberica Trevir. ex Spreng.

\section{Settlement (Site)}

There are two to three floors, historical Antakya houses reflecting the civil architectural samples of Ottoman period and many of them are used as housing even today. Fruit tree species and rapid growing tree species generally cover an important place in gardens and in open lands between houses; Citrus sinensis (L.) Osbeck, Citrus 
reticulate Blanco, Citrus paradise Macfad., Citrus limon (L.) Osbeck, Citrus aurantium L., Punica granatum L., Olea europaea L., Vitis vinifera L., Eriobotrya japonica (Thunb.) Lindl., Phoenix dactylifera L., Musa cavendishii Lamb., Morus alba L., Prunus domestica $\mathrm{L}$.

\section{Settlement (multi story)}

Multi story settlements take place in the new part of Antakya. These areas substantially endowed by exotic ornamental plants. Some of the most commonly seen tree and shrub species in these areas are similar with the parks. In the transportation routes, cosmopolitan and ruderal herb species are considerably pervasive depending on the land destructions occurred as a result of road construction activities. These are mostly cosmopolitan and ruderal species such as Avena clauda Durieu, Scolymus hispanicus L., Centaurea iberica Trevir. ex Spreng., C. solstitialis L., Xanthium strumarium L., Hordeum murinum L., Crepsis sp., Lactuca saligna L., Glycyrrhiza glabra L., Sinapis arvensis L., Raphanus raphanistrum L.

\section{Settlement (garden houses)}

These kinds of settlement take place between Habibi Neccar Mountain and settlement with site. These kind of settlement is dominates with shantytown.

\section{Other public institutions}

There some other public institutions like public building, military building in Antakya city. The sub biotope hosts the same plant with settlement.

\section{Non-built-up areas}

Sub biotope types grouped under forest, river bank, river and banks, maquie, garrique, open area, cover the 2351.79 ha of land. Forest covers 1238,7 ha, river bank 275,4 ha, river and banks 69,9, maquie 379,7 ha, garrique 285,6 ha, open area 102,5 ha.

\section{Forest}

Forest biotopes, Pinus brutia Ten. is the dominant tree. The biotope is seen in the Habibi Neccar Mountain where take place unbuilt central locations and in the suburbs of the city. This biotope hosts Quercus coccifera L., Q. infectoria G.Olivier, Arbutus andrachne L., Pistacia terebinhtus L., Rhus coriaria L., Cistus creticus L., Vicia cracca L., Iris unguicularis Poir., Eryngium palmatum Pancic \& Vis., Hypericum montbretii Spach, H. Triquetrifolium Turra, Cyclamen persicum Miller, Ophrys speculum Link var. orientalis.

\section{River and bank vegetation}

The most important water flow of the City is Asi (Orontes) River. Organic and chemical pollution resulting from residential, industrial and agricultural activities in the river bed negatively affect water quality, fauna and the flora. It host very rich flora such as; Ficus carica L., Eucalyptus camaldulensis Dehnh., Salix babylonica L., Celtis australis L., Phragmites australis (Cav.) Trin. ex Steud., Arundo donax L., Glycyrrhiza glabra L., Silybum marianum (L.) Gaertn., Centaurea iberica Trevir. ex Spreng., Ecballium elaterium (L.) A.Rich., Hordeum murinum L., Arundo donax L., Onopordum 
acanthium L., Torilis sp., Scolymus hispanicus L., Centaurea solstitialis L., C. iberica Trevir. ex Spreng, Inula viscosa (L.) Aiton, Echinops spinosus L., Verbascum sinuatum L., Saccharum ravennae (L.) L., Notobasis syriaca (L.) Cass., Sonchus oleraceus (L.) L.

\section{Garrigue}

These biotopes are easily sacrificed for different land uses to Sarcopoterium spinosum (L.) Spach. The other species; Euphorbia rigida M.Bieb., Ononis nartix L., Echium angustifolium Mill, Verbascum sinuatum L., Crepis sp., Alcea setosa (Boiss.) Alef., Calicotome villosa (Poir.) Link, Micromeria myrtifolia (Boiss. \& Hohen) Greuter\&Burdet, M. graeca (L.) Benth. ex. Rchb., Helichrysum stoechas (L.) Moench, Pallenis spinose (L.) Cass., Lolium sp., Avena sp., Dactylis glomerata L., Hordeum sp., Carthamus dentatus Vahl, Galium cassium Boiss., Salvia viridis L., Origanum syriacum L., Allium orientale Boiss. Carlina lanata L., Dianthus elegans var. cous.

\section{Maqui}

Quercus coccifera $\mathrm{L}$. is most dominant species. The other species are; $Q$. infectoria subsp. Boisseri(Reut.) O.Schwarz, Laurus nobilis L., Myrtus communis L., Crataegus monogyna Jacq., Styrax officinalis L., Arbutus andrachne L., Ceratonia siliqua L., Cistus creticus L., Erica manipuliflora Salisb., Pistacia terebinthus L., Rhus coriaria L., Juniperus oxycedrus L., Lavandula stoechas L., Hypericum perforatum L., Origanum syriacum L., Hedera helix L., Rubia tenuifolia d'Urv, Smilax excelsa L., Asparagus sp., Phillyrea latifolia L., Centaurea antiochia Boiss., Vicia cracca L., Trifolium purpureum Loisel., Ruscus sp., Michauxia campanuloides L'Her., Rubus sanctus Schreb., Cotinus coggygria Scop., Thymus sp.

\section{Agricultural area}

Agricultural area consists from agriculture (annual) and horticulture. Total land of agriculture is 2023,1 ha while subgroup of agriculture land is 1700,7 ha, subgroup of horticulture is 322,3 ha.

\section{Agriculture (annual)}

Agricultural areas main biotope group dominates in the study area. The plants observed in these areas mostly consist of weed species, such as Avena clauda Durieu, Scolymus hispanicus L., Centaurea iberica Trevir.ex Spreng., Centaurea solstitialis L., Xanthium strumarium L., X. spinosum L., Hordeum murinum L., Crepis foetida L. subsp. foetida, Lactuca saligna L., Glycyrrhiza glabra L., Sinapis arvensis L., Raphanus raphanistrum L.. Furthermore, there are also ruderal species. Some other species; Melilotus alba Desr. Clypera jonthlaspi L. Prosopis farcta (Banks\&Sol.)J.F.Macbr., Tribulus terrestris L., Sonchus oleraceus L. Papaver rhoeas L. Sorghum halepense L. Pers. Alhagi pseudalhagi (Bieb.) Desv., Vaccari pyramidata Medik. Solanum nigrum L., Amaranthus retroflexus L., Convolvulus arvensis L., Sonchus asper L. Hill., Portulaca oleracea L., Silene conidae L.

\section{Horticulture}

Olive groves sub biotope is among the leading biotopes destroyed due to 
urbanization. Olea europaea L. is the dominant tree in the biotope. These types of areas are generally covered by the cosmopolitan plant species.

After making biotope type evaluation map, the results are confirmed with field check. The map can be used as evaluation criteria for wildlife habitat conservation and land use control.

\section{Sensitivity assessment of biotopes}

To perform sensitivity assessment two parameters were used: rarity and reestablishment ability (Altan, 1997; Güzelmansur, 2000). The sensitivity assessment method of Altan (1997), explained in the Method section, was applied to the biotopes of Antakya city and the results are given in Table 2. Based on sensitivity results, 1.584 ha of the research area -forest, river banks and river and banks- is very sensitive, 454,6 ha of the research area -cemetery, settlement with site, and maquie- is sensitive land.

\section{Conclusions}

Maintaining sustainability for urban development is quite complex issue. There are several methods for this purpose. Sensitivity analysis with help of biotope mapping was used in the contribution. Rarity and reestablishment of defined biotopes used for sensitivity analysis. Vegetation analysis was conducted with importance of biotopes. Biotope mapping was also conducted to provide an ecological basis for sustainable urban development. So, the aim of the biotope maps can be specified to allow lands to be used under reflection of their environmental states. The results present that the builtup area are dominant biotopes in Antakya city. This has a great pressure on the natural species diversity. Urban area of Antakya city has been significant for almost four decades. Urban area is spreading out from 1821.531 hectare in 1987, 2601.473 hectare in 2001, to 2747.701 hectare in 2008 (Guzelmansur and K1lic, 2013). The study shows that urban population increases to 500.749 while urban area reached 3467.788 hectare. This shows that urban expansion is going on increasingly. Therefore, although it covers the smallest land in the study area, built-up areas biotope group which has a sprawled form creates a powerful impact in large areas with its high number of parcels in occurrence and increasing fragmentation of habitats. Habitat fragmentation is harmful for urban environment.

Built-up areas have been increasing year by year. Therefore, urban biotopes transform from natural to cultural damaging biodiversity of urban area. Some natural plant formations like Olea europaea L. are cut to construct new building. This situation shows that urbanization can cause reduction of dispersion areas of these natural species. Oppositely, cosmopolitan herbal species which have high dispersion and competitive capacity were also observed throughout the investigation area. Natural species which are non-tolerant from the viewpoint of habitat choice leave the area, while the cosmopolitan ones which can disperse easily in degraded areas become dominant. In this context, the most remarkable situation observed during the vegetation analysis was that natural species can have the possibility to live and disperse in urban areas on condition that their habitats are protected (Doygun et al., 2013).

Some precautions should be taken for maintaining sustainability of the urban biotopes which are under pressures of human activities. First of all, very sensitive sub biotope types need to be protected and then improved. Secondly, Antakya city needs an ecological planning approach in the structural planning process. Various authors argued that ecological knowledge should be integrated into urban planning and decision 
making for the maintenance of urban biodiversity (Lofvenhaft et al., 2002; Mansuroğlu et al., 2006, Janisova, 2014)

Biotope map was created using high resolution remote sensing data. High resolution satellite images like Worldview images can be used for biotope mapping in urban area by delineating land cover. It can save time and efforts for fieldwork. But the disadvantages of this kind of images are high prices. On the other hand some advantages of biotope mapping are the following: 1) It helps to provide basic information for land use plan which is important in defining priority for nature conservation. 2) It helps to develop programs for endangered species. 3) It helps to provide some recommendations for nature management. 4) It helps to provide basic information for green area. 5) It helps to provide an ecological basis for urban planning activities. To sum up, biotope mapping is very necessary for sustainable development and for sustainability.

The results presented in the paper show that object oriented classification is a valuable method for biotope mapping. Object oriented methods perform very well when applied to Worldview $(50 \mathrm{~cm})$. The method provides flexibility in the ability to transfer classification schemes developed recent images where a fair set of ground truth data is available.

The results produced by the sensitivity analysis can be used for management of sustainable land uses. Rarity and re-establishment factors are very important to maintain sustainability. Therefore the two factors can be used to determine sensitivity of biotopes to human disturbance. The disadvantage of the methodology is the difficulties to define rarity, because it is sometimes affected by users. On the other hand specification of all classes of re-establishment gives us an advantage.

Acknowledgements. Thank to Dr. Samim Kayıkçı who is a successful biologist for collaboration by investigations of plant and evaluation of the pilot study.

\section{REFERENCES}

[1] Altan, T. (1997): Imar Planlarina Ekolojik Planlamanin Katilimi ve Biyotop Haritalamanin Onemi. - II. Kiyi Sorunlari ve Cevre Sempozyumu, Kusadasi, Turkey, pp. $1-16$.

[2] Blaschke, T. (2010): Object based image analysis for remote sensing. - ISPRS Journal of Photogrammetry and Remote Sensing 65 (2010): 2-16.

[3] Bock, M., Xofis, P., Mitchley, J., Rossner, G., Wissen, M. (2005): Object-oriented methods for habitat mapping at multiple scales-Case studies from Northern Germany and Wye Downs, UK. - Journal for Nature Conservation 13(2): 75-89.

[4] Cserhalmi, D., Erdős, L. (2016): Accuracy assessment of retrospective vegetation maps considering succession patterns. - Applied Ecology And Environmental Research 14(1): 37-45.

[5] Davis, P. H., Mill, R.R., Tan, K. (1988): Flora of Turkey and The East Aegean Islands (Supplement). - Edinburgh University Press, Vol. 10, Edinburgh.

[6] Doygun, H., Ilçim, A., Atmaca, M. Oğuz, H. (2013): The Importance of Biotope Mapping from the Viewpoint of Protection of Urban Environment and Sustainable Urban Development: The Case of the City of Kahramanmaraş. - Turkish Journal of Scientific Reviews 6 (1): 33-37.

[7] Foody, G.M. (2002): Status of land cover classification accuracy assessment. - Remote Sensing of Environment 80:185-201. 
[8] Frey, J. (1999): Practical aspects of biotope mapping in cities: methods, problems and solutions. An example of Mainz, Germany. Biotope mapping in the urban environment. Deinsea 5: 41-5.

[9] Gitas, I. Z., Mitri, G. H., Ventura, G. (2004): Object-based image classification for burned area mapping of Creus Cape, Spain, using NOAA-AVHRR imagery. - Remote Sensing of Environment 92(3): 409-413.

[10] Guzelmansur, A. (2000): Analysis of coast land use and alternative landuse proposals for Erzin Sarımazi-Burnaz Beaches and some holiday house in coastal zone of Erzin. Çukurova University, Institute of Natural and Applied Sciences, Department of Landscape Architecture, MScThesis.

[11] Guzelmansur, A., Kilic, S. (2013): Land-Cover Classification Using Advanced Land Observation Satellite Imagery: A Case Study of The Peri-Urban Region of Antakya. Journal Of Food Agriculture \& Environment 11(2): 1178-1181.

[12] Ivits, E., Koch, B., Blaschke, T., Jochum, M., Adler, P. (2005): Landscape structure assessment with image grey-values and object-based classification at three spatial resolutions. - International Journal of Remote Sensing 26(14): 2975-2993.

[13] Janišová, M. (2014): The role of surrounding landscape in determining species richness of mesic grasslands in pannonian basin and carpathian mountains. - Applied Ecology and Environmental Research 12(1): 251-266.

[14] Katarina, L., Björn, C., Ihse, M. (2002): Biotope patterns in urban areas: A conseptual model integrating biodiversity issues in spatial planning. - Landscape and urban planning 58: 223-240.

[15] Kaule, G., Schober, M. (1985): Ausgleichbarkeit von Eingriffen in Natur und Landschaft. - Schr. R. Bmelf Reihe AH. 314, Munster-Hiltrup.

[16] Lehmann, I., Mathey, J., Rößler, S., Bräuer, A., \& Goldberg, V. (2014). Urban vegetation structure types as a methodological approach for identifying ecosystem servicesApplication to the analysis of micro-climatic effects. - Ecological Indicators 42: 58-72.

[17] Li, F., Liu, X., Hu, D., Wang, R., Yang, W., Li, D., Zhao, D. (2009): Measurement indicators and an evaluation approach for assessing urban sustainable development: A case study for China's Jining City. - Landscape and Urban Planning 90(3): 134-142.

[18] LoFvenhaft, K., Bjorn, C., Ihse, M. (2002): Biotope patterns in urban areas: a conceptual model integrating biodiversity issues in spatial planning. - Landscape and Urban Planning 58 (2-4): 223-240.

[19] Mansuroglu, S., Ortacesme, V., Karaguzel, O. (2006): Biotope mapping in an urban environment and its implications for urban management in Turkey. - Journal of Environmental Management 81:175-187.

[20] Mathieu, R., Freeman, C., Aryal, J. (2007): Mapping private gardens in urban areas using object-oriented techniques and very high-resolution satellite imagery. - Landscape and Urban Planning 81(3): 179-192.

[21] Meinel, G., Neubert, M., \& Reder, J. (2001): The potential use of very high resolution satellite data for urban areas-First experiences with IKONOS data, their classification and application in urban planning and environmental monitoring. - Regensburger Geographische Schriften 35: 196-205.

[22] Myint, S. W., Gober, P., Brazel, A., Grossman-Clarke, S. Weng, Q. (2011): Per-pixel vs. object-based classification of urban land cover extraction using high spatial resolution imagery. - Remote sensing of environment 115(5): 1145-1161.

[23] Repaka, S. R., Truax, D. D., Kolstad, E., O’Hara, C. G. (2004): Comparing spectral and object based approaches for classification and transportation feature extraction from high resolution multispectral imagery. - ASPRS Annual Conference Proceedings, pp. 23-28.

[24] Sukopp, H., Weiler, S. (1988): Biotope mapping and nature conservation strategies in urban areas of the Federal Republic of Germany. - Landscape and Urban Planning 15 (12): $39-58$. 
[25] Tüik, (2016): Turkish Statistical Institute, official website. https://biruni.tuik.gov.tr/medas/?kn=95\&locale=tr, date of acces: January 2016.

[26] Van der Sande, C. J., De Jong, S. M., De Roo, A. P. J. (2003): A segmentation and classification approach of IKONOS-2 imagery for land cover mapping to assist flood risk and flood damage assessment. - International Journal of applied earth observation and geoinformation 4(3): 217-229.

[27] Yu, W., Zhou, W., Qian, Y. Yan, J. (2016): A new approach for land cover classification and change analysis: Integrating backdating and an object-based method. - Remote Sensing of Environment 177: 37-47.

[28] Zhou, W.Q., Troy, A. (2008): An object-oriented approach for analysing and characterizing urban landscape at the parcel level. - International Journal of Remote Sensing 29: 3119-3135. 